\title{
Small regimes in the Middle East: a conceptual and theoretical alternative to small states in a non-Western region
}

\author{
Máté Szalai ${ }^{1,2,3}$ (D)
}

(c) The Author(s) 2020

\begin{abstract}
The concepts and theories of small state studies, a sub-discipline of international relations, have been connected to Western political development, making their applicability in regions outside of Europe questionable. Using the framework of the English School, the present article aims at identifying the main elements of small state theory which are needed to be altered to make it suitable for the Middle East and North Africa. Investigating the regional manifestation of main primary institutions which form the basis of the analysis of small states (namely statehood, sovereignty, conflict and cooperation), the research concludes that the leverage of Middle Eastern small states is highly different than it is expected by traditional small state studies, especially due to the regional norms related to statehood and conflict. Consequently, changing our conceptual framework of "small states" to "small regimes" would be also necessary to better interpret how such entities behave in the Middle East or other regions of the world.
\end{abstract}

Keywords Small states · English school · Middle Eastern studies · Gulf states · Regimes

\footnotetext{
Máté Szalai

mate.szalai@uni-corvinus.hu

1 Budapesti Corvinus Egyetem, Budapest, Hungary

2 Corvinus University of Budapest, Budapest, Hungary

3 Institute for Foreign Affairs and Trade, Budapest, Hungary
}

A previous version of the paper was presented at the Gulf Research Meeting 2019. 


\section{Introduction}

The research agenda of small state studies has always lacked a regional perspective, mainly due to three reasons: First, mainstream theories of IR usually suggest that state size is the key variable determining foreign policy due to the nature of the international system, labelling most of the other factors irrelevant (see Waltz 1979; Neumann and Gstöhl 2006). Secondly, theories aiming at defying the mainstream assumptions (especially neoliberal institutionalists and constructivist) either keep the (global) systemic viewpoint or jump immediately to the individual level of analysis, leaving the regional level untouched. Even innovative attempts (like Gigleux 2016 or the comparative studies in Archer et al. 2014) attempt only to connect the state and the structural level or limit themselves to an empirical comparison without deep theorisation. Third, theoretical schools which possess the toolkit to understand regional particularities (e.g. world system theory or regional security complex theory) are yet to have a substantial impact on the study of small states.

Nevertheless, regional differences can extremely alter the leverage and behaviour of small states. One can hardly question that a resource-scarce country located in the European Union or in the Persian Gulf has a strategically different situation, not just due to the alterations of the geopolitical environment but to diverse normative circumstances as well. Such regional particularities should change how we view not just the status but the very nature of small states toowithout proper investigation, we cannot be even sure that the basic principles which guide our expectations vis-á-vis small state behaviour are valid in a specific geopolitical and normative environment. The present article attempts to identify the necessary alterations to traditional small state theory deriving from the particularities of the Middle Eastern and North African (MENA) region. Using the vocabulary provided by the English School (ES) of International Relations, my main argument is that due to the altered manifestation of primary institutions like "state" and "sovereignty" as well as "conflict" and "cooperation" in the MENA region (or other regions), the notions of mainstream small state studies are inapplicable.

Altering our traditional conceptual framework and viewpoint nevertheless enables us to detect different behavioural patterns. As a result of the investigation, I will argue for widening the vocabulary of small state studies and altering the usual unit of analysis from "small states" to "small regimes", as the latter term, in specific normative environments, mirrors the nature of the actor in a more precise way. While the term is used to describe Middle Eastern small states, it can be applicable to actors with similar characteristics in other regions.

The article is divided into three parts: First, I will draw up the basic theoretical framework of the article building on the notions of ES and identify the primary institutions which set the leverage of small states. Second, I will move on to the investigation of such primary institutions in the MENA region and provide short case studies to demonstrate their importance. Third, I will summarise my 
suggestions of alterations of small state theory to be applicable for regions outside of Europe.

With the analysis, I wish to contribute to three contemporary academic endeavours in the IR literature: Firstly, to bridge the gap between theoretical and applied IR in Middle Eastern Studies (MES); secondly to contribute to the growing literature in regionalising mainstream theories of IR; and thirdly, to reassess the present focal points of small state studies which "may put too much emphasis on power and size and too little on the status of statehood" (Baldacchino 2014: 242).

\section{Interpreting regional differences and smallness in the English School framework}

Despite its decades-long history, the English School can still be considered as an emerging research programme in IR. Its basic idea is that the international system can be conceptualised as an "anarchic society" (a society of states) which incorporates elements of anarchy as well as formalised and institutionalised relations at the same time (that is why neither realism, nor liberalism can be used as a holistic theory). In order to minimalise harm, to uphold agreements and to ensure possessions (Bull 2002: 4; Schouenborg 2014: 80), members of the society developed primary institutions - namely a "set of habits and practices shaped towards the realisation of common goals" (Bull 2002: 71) which "are evolved more than designed", represent "fundamental and durable practices" and shape the leverage of political actors as well as their "patterns of legitimate activity in relations to each other" (Buzan 2004: 167). Such abstract notions are protected and maintained through secondary institutions, i.e. "physical regimes or organisations" (Schouenborg 2014: 80).

Naturally, the exact list of primary institutions is hard to make. Many different notions have been mentioned by researchers including the five "classic ones" described by Headley Bull (diplomacy, war, balance of power, international law and great powers). These individual lists are heavily criticised and debated in the literature (Buzan 2004: 174). The discussion covers also the hierarchy between said institutions, the relationship between master and derivative institutions.

Despite having a systemic approach, the English School is quite effective in identifying and interpreting differences between regional sub-systems of the international society. While regionalism is not a primary feature of the ES literature, many argue that the "global society is unevenly developed to a very marked degree" (Buzan 2004: 208). The reason lies in the origins of the international society, a mostly European construct which spread across the rest of the world through colonialism and other forms of encounters and was solidified after decolonisation, opening up the society to the "Third World" (Buzan and Little 2014: 61). ${ }^{1}$ While in theory, the process included the transfer of Western political forms (such as states) to the rest of the world, nevertheless in practice, these legal (and cultural) models never managed to

\footnotetext{
1 See Yost (1979) for a discussion of works of F.S. Northedge, Martin Wright and Hedley Bull on different historical state systems and their interactions.
} 
completely overcome "the complex and competing forces that they encountered on the ground" (Buzan and Little 2014: 62) such as tribal affiliations and other forms of collective self-help systems (Salzman 2016). This led to either a sort of pluralism and/or mixture of local and "global" institutions and norms. This process, labelled "norm subsidiarity" (Acharya 2011: 96), results in differences between various subregional systems (e.g. the European and the Middle Eastern one) and the global system and a specific sub-regional system (e.g. the global and the Middle Eastern one).

A few specifics endeavours have already been made in the literature to understand regional systems or institutions through the application of the English School, e.g. that of Narine (2006) regarding the ASEAN region, the analysis of Stivachtis (2008) regarding the expansion of the European Union and its norms, or the edited volume of Buzan and Gonzalez-Pelaez (2009) on the Middle Eastern international society. Costa-Brunelli (2015) conceptualises such geopolitical constructs as "linguistic contexts" which actually give different meaning to the same institutions (such as sovereignty). This means that even in the highly unlikely scenario that the same primary institutions are strong to the same extent in all regions, the regions themselves would not necessarily work the same as they can give different meaning and substance to the "common" rules.

Contrary to regional differences, the English School "has surprisingly little to say about (...) small states" (Maas 2005: 1). ${ }^{2}$ As small state studies evolved mostly in the neorealist, neoliberal and the constructivist framework (Neumann and Gstöhl 2006: 16-17), "other theoretical traditions", including the ES, "devote more time and attention to larger states, or great powers, than they do to small states" (Neal 2017: 34). Nonetheless, the investigation of the regional alterations of primary institutions can have severe added value to the study of small states - a notion echoed by Chong and Maas (2010: 382) who urged English School scholars to pay more attention to small states.

That call, so far, has been mostly neglected. The most notable exemption was a paper written by Maas (2005). ${ }^{3}$ His research question was whether the anarchic society that has emerged in the last centuries is beneficial for small states or not. Through the investigation of the development of the international society since the seventeenth century, he arrives to the conclusion that the exact meaning of both power and size "can only be determined if it is compared to the overall system".

The most important lesson provided by the analysis of Maas is that the position of small states has been shaped by the evolution of the primary (and secondary) institutions of the international society. For most of the researches in small state studies, "the starting point of analysis remains the realist leading of power" (Chong and Maas 2010: 382). Therefore, the observations they make usually point to the security deficit and weakness arising from smallness, leading to a limited under-the-radar

\footnotetext{
2 Small states will be defined as those states whose territory, population, economic output and military capacities are below the average of a given region.

3 Besides him, Wight (1978) wrote about weak actors of international relations; nevertheless, his conceptual framework does not exactly fit that of small state studies.
} 
foreign policy which prefers international organisations and law, bandwagoning and diplomatic settlement of disputes.

This observation also suggests that if specific primary institutions are altered in different eras and regions, the leverage of small states is also subject to change. The most important question is which are the primary institutions which effect the situation of small states to the greatest extent. Reviewing the literature, my argument is that two pairs of such norms should be in the focus of investigation.

The first of these is "state" and "sovereignty". Depending on the conceptualisation of statehood, size can have different consequences. In the neorealist framework (Waltz 1979: 87-89), states are functionally identical actors in world politics, which "are differentiated from one another", "not by function but primarily by capability. (...) Inequalities across states have greater political impact than inequalities across income groups within states" (Waltz 1999: 698). Consequently, states are basically black boxes which should be considered the sovereign actors on their territories. Neoliberals, on the other hand, have a different understanding of states and sovereignty. They argue that the domestic and international institutional environment of states determines their international behaviour to a great extent, depriving size of being the single most dominant independent variable of foreign policy. Katzenstein (1985) described how the political culture and flexible economic system of small European states led to their resilience during major economic crises. Besides him, many writers_-including Vital (1967) or Thorhallson (2006) —investigated how the institution building of foreign policy frameworks inside small state effects their relations with other states and international organisations. Recently, a few attempts have been made to tackle various manifestations of statehood in small state studies (e.g. Chong 2014 or Taylor 2014), but only on a case study basis.

The second pair of primary institutions which is a matter of difference between the three schools of small state studies is "conflict" and "cooperation". In an environment where armed conflict is allowed and seen as an everyday phenomenon, small states face constant threats from the outside. But if regional politics are constructed in an institutionalised, cooperative manner (like in Europe), small states are safer and have the potential to be more influential. The most striking difference between the neorealist and neoliberal school derives from the different description of the importance of conflict and zero sum games in international anarchy. ${ }^{4}$ In order to form our expectations regarding the behaviour of small states in a specific regional system, first we have to understand the local manifestation of the norm pairs of "state" and "sovereignty" as well as "conflict" and "cooperation".

\footnotetext{
${ }^{4}$ While not using the vocabulary of the English School, Wivel et al. (2014: 21) arrived to similar conclusions regarding the importance of these norms. Upon the comparison of the security of small states inside and outside Europe, they argued that in the investigation of regional and sub-regional particularities have explanatory value if it includes "the local concept of statehood" (i.e. the primary institutions of "state" and "sovereignty") and "of interstate relations" (i.e. norms related to conflict and cooperation).
} 


\section{State and sovereignty in the Middle East and North Africa}

\section{Changing the agent: "states" and "regimes"}

The variety of polities and social organisation formats we usually call "states" constitutes the primary type of organised and institutionalised political communities. The most influential type of such organisations is the modern or Westphalian state, which has been the cornerstone of international relations since the seventeenth century. While this concept is still hard to define, we can set the minimal criteria with which an institution should be attributed with in order to call it a modern state (Coporaso 2000: 8-11). These include:

- authority (the recognised right to rule over a specific territory and people);

- sovereignty (being the final authority, having the ultimate right to decide);

- territoriality (the jurisdiction should be attributed with spatial boundaries); and

- citizenship (institutionalised membership in the political community based on explicit rights and responsibilities).

This model, which is built on Weberian and international legal viewpoints, is taken by granted by various disciplines in IR, including small state studies. Nevertheless, this concept focuses on the juridical attributes of statehood and not its empirical manifestation (Jackson and Rosberg 1982: 3) which can vary considerably due to historical reasons. Modern statehood-as a primary institution of the Europe-born international society—got exported to other regions in two steps: First, Western empires constituted the institutional framework in a top-down manner, after which local leaders provided the content to it (Hinnebusch 2018: 392-393.). This content comprised mostly of local traditions, the narrative of the elites regarding modernity and their attempt to strengthen their power. This process led to markedly different concepts of statehood and sovereignty in different regions-the post-colonial Asian small states, which were build upon Buddhist notions and the so-called mandalic system (Chong 2014) work and behave differently than e.g. the African development state (Taylor 2014).

In the Middle Eastern context, the process started out as a voluntary development conducted by the Ottoman empire in the nineteenth century, as the leaders perceived their relative decline; thus, they started to copy Western institutional solutions. In parallel with this "defensive modernisation" (Anderson 1987: 5.), the British and French governments expanded their influence in the MENA region and started to forcibly change local political and social institutions. This coerced modernisation, which continued with the mandate system, led to the creation of most of the currently existing Arab states.

The new rulers, let them be pro- or anti-Western, accommodated and accepted the Westphalian system as they built up their authority, they limited their aspirations geographically, and they started to engage in a realist competition among themselves despite the general pan-Arabic rhetoric (Lawson 2000: 529). Naturally, the process did not happen overnight—according to Hinnebusch (2014: 36-54), it was only in 
the 1970s that state-building efforts resulted in profoundly realist foreign policy calculations-but it definitely led to a regional system of nation-states which, at first glance, fulfils the criteria of modernity.

In practice, nonetheless, the situation is more complex. Statehood in the Middle East is an example of linguistical alterations of specific global primary institutions proposed by Costa-Brunelli (2015). The word "state" (daula in Arabic, doulat in Persin and devlet in Turkish) appears in the regional political discourse to describe modern states, though it incorporates a slightly different meaning (N. Rózsa 2018: 17-18). Until the twentieth century, the world had not referred to the concept of modern state, but rather to "the high office and authority of the person on governance" and to the institutions through it governs (ibid). Throughout history, political power has been exercised through other types of institutionalised political communities, including tribes and empires, a phenomenon which continued to effect political dynamics even after the formal introduction of modern states in the nineteenth-twentieth century. The result has been a mixture of old and new attributes which created a markedly different framework than IR is used to as a discipline.

To understand the function of the Middle Eastern state, the best way is to enlist the basic alterations vis-á-vis the idea of Westphalian state. Hinnebusch (2018) summarised the most important differences in the following points:

- Identity/territorial incongruity: The pre-Westphalian structure of the regional society was built on identity units smaller (e.g. tribes) and larger (e.g. the umma) than national communities. As a result, state-promoted national identities have always had to suffer competition both from inside and outside of state boundaries.

- Hybrid power technologies: The Weberian legal rational authority was also imported with the modern state system, which incorporated the already existing power accumulation techniques, resulting in a hybrid political culture. The concept of neo-patrimony (Sharabi 1988) refers to a similar phenomenon.

- Semi-sovereignty to neo-medievalism and heterarchic non-Westphalian governance: As a result of weak institutional structures, the constant intervention of external powers and unpreparedness for globalisation, Middle Eastern states suffer a loss of their sovereignty and their power is partly transferred to sub- and supranational actors.

- Nonlinear trajectories: State-building efforts did not take place as a constant progressive development but rather a bell-curved shape which peaked in the 1970s but started to decline as a result of market-oriented reforms in the 1990s.

- Failing statehood and proxy wars: Due to all these attributes of statehood, state institutions did not manage to strengthen themselves and to exercise complete authority. This can easily result in civil wars and exposure to external power competition.

As a result of all these phenomena, the actor of Middle Eastern international politics is not necessarily the state itself but rather the regime (Brichs 2013; Brichs and Lampridi-Kemou 2013). Throughout history, different local elites (tribes, religious groups, etc.) fought for power in the MENA region, a competition which was not 
ended but transformed by the rise of modern state structures. The state was considered to be the ultimate resource in the rivalry, and the elite groups which managed to get the control over it did everything to reproduce its dominance. As a result, the ruling elites merged with some state institutions, resulting in the creation of regimes. This dynamic constantly reproduces the weakness of state legitimacy, as it inherently built on exclusion and neo-patrimonial structures of families, clans or tribes (Sharabi 1988: 35).

The regime structure is not uncommon in other regions after decolonisation (Jackson 2009), and the argument can be made that smallness of the state incentivises its development. Despite the theoretical discussion in comparative politics regarding the connection between democracy or power-sharing culture and small state size, empirical investigation shows that "smallness produces a variety of informal mechanisms that undermine democracy", especially "clientism, personalistic politics and executive domination" (Veenendaal 2020: 80). As a result, the "omnipotent and ubiquitous" state is more likely to be captured by elites and will work "as the employer of last resort, and a (...) person-driver apparatus that dispenses (...) benefits, especially to the politically sympathetic" (Baldacchino 2014: 247).

This particularity has many consequences for the behaviour of actors dressed as "states". For a regime, the Westphalian dichotomy of domestic peace and external anarchy is not paramount. Regimes implement an "omni-balancing strategy", always turning one eye to the domestic challengers of their rule (David 1991; Colombo 2017: 56-58), which blurs the line between domestic and foreign policy. Such a behaviour is not unique to the MENA region, e.g. in the case of South-Asian small states, Chong (2014: 206) also observes an "intermestic" concept of security, arguing that "the management of small states' problems requires constant calibration between domestic and external pressures".

Consequently, the main line of division will not lie between the domestic and the foreign sphere but between the intra-regime and extra-regime sphere. Everything outside of the regime (let that be inside or outside of the "national" borders) will be considered as potentially hostile, questioning the institution of citizenship in a Westphalian sense. The peace of the domestic sphere is transferred to the intra-regime sphere, where political dynamics are markedly different than outside of it. ${ }^{5}$ Similar to the Westphalian domestic sphere, if a problem occurs inside the regime, it is usually a grave concern that can undermine governability to a great extent.

As it is easily observable, the above described circumstances effected all states in the MENA region regardless of their size. Nonetheless, I would argue that due to a number of reasons, the particularities of the Middle Eastern state system are actually beneficial for small states.

First, states of the MENA region cannot draw a protective line between domestic and foreign politics, exposing them to the outside environment. They are inherently "weak penetrated states" (Hinnebusch 2018: 392) from the perspective of the

\footnotetext{
5 That is the reason behind the observation made by Northedge (1976: 172) regarding the foreign policy of post-colonial states not being determined by systemic developments but internal "requirements" (i.e. regime security).
} 
international society; therefore, in international politics, intervening in each others' domestic affairs is a common practice (Halliday 2009: 15-17). This can be beneficial for small states in two ways: First, interference is a more efficient tool than waging war against one another, which lowers the chances of traditional interstate wars, the most frightful scenario for small states. Second, the ability to interfere into each other's domestic affairs or to withhold such an endeavour is not linked exclusively with the possession of material resources. The former is not necessarily an expensive tool and can only require an effective soft power strategy while the latter is pretty much dependent on social cohesion and the management of social grievances. While material resources are necessary for both, but they do not require as much as e.g. building up a national competitive army.

Second, due to the weakness of states, there is a large room to manoeuvre for non-state actors, especially Islamic movements (including charities, networks and political parties), violent groups questioning the monopoly of the state to use legitimate power (Valensi 2015) or NGOs. While such actors definitely possess agency, they can easily be used as foreign policy tools (Kausch 2017; Marchetti and Al Zahrani 2017). Such instruments are effective in interfering in other states' domestic affairs and are cheaper than traditional coercive methods and thus can easily be used by small states as well-moreover, they do not have a comparative disadvantage in doing so. One can think of Qatar and its relationship with the Muslim Brotherhood as an example.

Third, due to omni-balancing, larger states are discouraged from the traditional militarisation of international politics (the ultimate fear of small states). Since all regimes have to care about the domestic consequences of their foreign policy actions, building up an over-excessive army does not come without any political costs. Due to a phenomenon which is called the "insecurity dilemma" (Jackson 2009: 148), the development of coercive capacities can easily harm the balance between domestic elites, as opposition groups consider such steps as threatening their survival, incentivising them to stand up against the government. This does not mean that militarisation is out of the question, but it comes with the price of endangering domestic peace. This represents not just a limitation for larger states but also a possibility for smaller states to intervene in the domestic affairs of larger states and cause problems in the backyard of the regimes.

As a result, the regional manifestation of the modern state phenomenon has in general a positive effect on the position of small states as it shrinks the gap between the power they and larger states can exercise. While their security is also diminished by the penetrability of domestic affairs, so is their larger neighbours'; on the other hand, they are vested with non-traditional tools (e.g. the usage of non-state actors) which enlarges their leverage. This points to the conclusion that the realist idea of the congeniality of states is invalid in the MENA system.

\section{Case study: comparing the case of Qatar and Bahrain}

Though the small Gulf states are not identical in size, they have a systemically alike situation. As it is predicted by small state theory, the security of the five states got 
exposed to the developments taking place in their neighbourhood, including the three Gulf wars, the foreign policy changes in Saudi Arabia, Iran and Iraq, and the rising instability in Yemen and Iraq. Nonetheless, their security perceptions and behaviour differed to a great extent in the last decades, a phenomenon which can be attributed to the above described particularities of the Middle Eastern state. To prove that turning our attention to regimes is vital to understand the foreign policy differences between "small states" having systemically similar positions, I will compare the case of Qatar and Bahrain. I argue that the different intra-regime dynamic and the different level of social cohesion in the two states, in the Middle Eastern context, matter more than size.

At first glance, the Bahraini and the Qatari regime seems very similar to each other (Byman and Green 1999; Crystal 2014; Davidson 2012; Ismael and Ismael 2011). Both are based on the alliance between a Sunni family (the Khalifa and the Thani, respectively) and the British empire which manifested in a bilateral agreement. Both political systems are characterised by centralised and personalised decision-making and rentierism. Both states have a monarchic system, a written constitution, and both include some form of representative consultative bodies but centralise political and economic power.

In spite of these similarities, there are two major dimensions in which the Bahraini and Qatari system is profoundly different, both of which gain importance due to the special nature of the Middle Eastern states. The most important difference between the two states is observable in terms of social cohesion. The Khalifa family has always fought with domestic opposition in the Bahraini society due to at least three reasons (Kinninmont 2011: 32; Louer 2014: 118-119): The majority of the population is Shia; the family does not originate from Bahrain and consequently is not part of the indigenous Baharna population, and many criticise the monarchic structure as a form of government. These grievances are coupled with, according to social memory, the warfare resulting from economic mismanagement, which leads to a long-term lack of competitiveness in Bahrain (Fuccaro 2009: 16-42). As a result, the Bahraini government has always had to face chronic dissatisfaction from the population, resulting in a series of large-scale protests between the 1920 s and the 1970s (Ulrichsen 2014: 334-335).

Besides the utilisation of the traditional rentier logic, the main tools in the hands of the regime have been limited steps of liberalisation (Crystal 2014: 172) and strengthening the sectarian narrative (Diwan 2014: 144). Due to the Iranian revolution, it was not difficult to build on the anti-Iranian sentiments of Sunni communities on the other side of the Persian Gulf; that is why securitising the "Shia threat" has been effective. This tool came in handy during the "Arab Spring" events in 2011 (Matthiesen 2013: 33-49; Khalaf 2013), when, after a failed attempt to appease the demonstrators with promise of a direct financial transfer to each families (Barany 2012: 23), the government managed to de-incentivise many of the Sunni protestors by emphasising the sectarian nature of the demonstrations. Eventually this was not enough, and the government turned to the help of the GCC which implemented a short supportive intervention to ensure the survival of the regime.

Due to the lacking social cohesion and the sensitive social cleavages, Bahrain got exposed to outside interference. Iran, on the one hand, managed to enlarge its 
influence through the Shia Islamist networks, not necessarily after 1979, but rather in the 2010s. Saudi Arabia, on the other, also enlarged its influence over the decision-making of Bahrain since 2011. Riyadh has already had considerable influence in the island state, due to the perceived Iranian threat and the close economic relations between the two states, but since the Bahraini Spring, the dependency of the regime on Saudi support deepened. One manifestation of the growing Saudi influence is the growing pressure on the Bahraini Muslim Brotherhood network (centred at the Islamic Mimbar society), which historically has been closer to the government than to the Shia opposition (despite all ideological differences), but recently the regime pushed back against them (Freer and Cafiero 2017). This seems like in line with the Saudi security interests, and not necessarily the Bahraini ones. Also, in 2018, some news surfaced about the Saudi and Emirati pressure on removing prime minister Khalifa bin Salman Al Khalifa from his position (Middle East Eye 2018).

In contrast, social cohesion is much stronger in Qatar. Due to the lack of considerable economic capacities before the discovery of hydrocarbons and the peripheral position of the country, the economic elites never managed to balance the ruling family's power. The Shia population (considered to be around $20 \%$ of the society) has always been well integrated without any considerable anti-establishment aspirations (Kamrava 2014: 161).

Such level of social homogeneity allowed the Qatari government to have a wider leverage as outside actors did not manage to penetrate the Qatari society to a dangerous extent. Even after the time of the Gulf rift of 2017, the Saudi leadership and its allies did not manage to build up a considerable opposition to the current leadership. Moreover, the public support of the leadership was visible after 2017, and while it was probably partly an organised political campaign, it had a social background.

Social cohesion did not only defend Qatar from outside intervention but also enlarged its foreign policy leverage. The omni-balancing efforts of the regime did not have the necessity to constantly bearing in mind the domestic consequences of their actions on the international level. That allowed the Thani family to build relations with regional and global players without any trade-offs-this resulted in the ability to build up a hedging strategy (Kamrava 2014: 167-181) which aims at maintaining stable relations with anyone.

The other dimension in which there is considerable difference between the two states is intra-regime dynamics. Historically, the Bahraini leadership has been somewhat unified without any spectacular internal fights-the only succession since independence took place in 1999 after the death of Isa bin Salman Al Khalifa. He was followed by Hamad bin Isa Al Khalifa, who was the designated heir since 1994. Another sign of stability is the fact that the aforementioned Khalifa bin Salman Al Khalifa has held prime ministership since independence (Kinninmont 2011: 40).

The most important intra-regime development recently was the rise of the Khawalid branch of the Khalifa family. Members of this branch were forced out of the country in the early twentieth century due to their opposition of deepening British-Bahraini ties and their deep anti-Shia sentiments (Diwan 2014: 162-163). After the succession of 1999, the Khawalid were able to get closer to power (as the mother of the new emir also belongs to this branch), notably with Minister of Defense Khalifa bin Ahmed and Minister of the Royal Court Khaled bin Ahmed. Their sectarian 
views heavily contributed to the growing sectarian discourse which was constantly reproduced by the regime after 2011 (Gengler 2013).

The rise of the Khawalids effected the foreign policy of Bahrain as well. The harsh anti-Shia approach represented by the branch is very compatible with the current Saudi leaderships regional vision, which is why they are known to be close to Riyadh. For example, in 2011, they supported the Gulf Union initiative of Saudi Arabia, which was vehemently rejected by other GCC members (Guzansky 2015: 25-28; Wehrey 2013: 135-136).

While the Qatari regime is considered to be functioning without any serious internal cracks, historically this has not been the case. Since independence, two forceful successions took place-in 1972 and 1995 (Kamrava 2013; Crystal 2014). The first peaceful power transition went through as late as 2013, when Hamad bin Khalifa Al Thani was replaced by his son, Tamim bin Hamad Al Thani. Among these successions, the one in 1995 had the gravest importance as it changed the foreign policy of the country profoundly. Emir Khalifa, who ruled between 1972 and 1995, conducted a low profile foreign policy, mostly following the lead of Saudi Arabia. Nonetheless, when he was forced to give the throne to Hamad, the new emir did everything to push his father's men out of power. This practically meant a break-up with Riyadh as well, since the Saudis (preferring stability over unpredictability) organised a reactionist coup attempt against Hamad.

This is one of the main roots of the anti-Saudi foreign policy of Qatar for the next two decades. The tensions between the Thanis loyal to Hamad (which includes his son, Tamim as well) and those preferring a pro-Saudi stance represented by Khalifa came into picture after the Gulf rift of 2017, after which Riyadh started to build up a royal opposition to Tamim, without any apparent success.

As one can clearly see, intra-regime struggles and social cohesion heavily effect the foreign policy leverage and strategy of both Bahrain and Qatar. In the former case, the rise of the Khawalid branch contributed to the sectarian policies after 2011, which, due to the lack of national cohesion, opened up the country to Saudi (topdown) and Iranian (bottom-up) interference. When it comes to Qatar, social homogeneity enabled the regime to conduct a more independent foreign policy, but the violent succession process of 1995 put the country on a collision course with Saudi Arabia. These developments gain importance and meaning in the context of the modified primary institution of the modern state in the MENA region.

\section{Small regimes in the regional Millieu of conflict and cooperation}

\section{Norms related to conflict and cooperation}

War has always been constituted as a norm in the interstate society of modern states; nonetheless, its substance and its legal and normative limitations have varied extensively. As it was already mentioned, one of the motives behind the creation of rules for the interstate society was to avoid a full-scale armed conflict, but that does not mean that the use of force was excluded as a social practice or as a "settled pattern of behaviour" (Bull 2002: 178). 
The substance of the norm of "war" has changed profoundly in the last century on the global level. The legitimacy of attacking another state narrowed down considerably (Buzan 2004: 182); Buzan even argued for the replacement of the norm to "great power management", which suggests that the current rules of the interstate society deprive states of the possibility to pursue wars for self-interests and only allows them to use force in the case of a collective goal (set by the Security Council) or self-defence.

While one can easily think of the MENA region as a conflictual society, the question is more complicated. The Middle Eastern system had many armed conflicts (e.g. between Israel and its neighbours or the Gulf wars) as the developments which limited the usage of armed force on the global stage (namely interdependences, democratisation and institutionalisation) have been absent in the region, creating a highly unstable environment (Hinnebusch 2014).

Balance of power dynamics incentivised war as well. Due to the penetrated nature of the MENA region and to the inherent institutional weakness of states, a regional hegemon has never been able to arise. The presence of global powers and their domestic weaknesses limit the leverage of regional pillars, making power more dispersed on the international level (Commins 2014: 2). This phenomenon actually accelerated since 2011 , resulting in a competitive multipolarity (Kausch 2014). Lacking hegemony-while enlarges the influence of small and medium-sized powers-makes the eruption of interstate wars theoretically more likely as there is no actor in the society which is able to provide peace as a public good.

On the other hand, there are existing regional norms which limit the political ability of states to start traditional wars. The most important among these is Arab solidarity — due to the supranational nature of Arabism, nationalism has not driven conflict but provided a normative basis of togetherness of states and their communities. Until 1990, when Iraq attacked Kuwait, these norms prohibited Arab states to start an armed conflict against each other (Gonzalez-Pelaez 2009: 105), delegitimising traditional war as a political tool in inter-Arab politics.

The prohibition of interstate wars between Arab states is rooted in both history and culture and not in material variables investigated by neorealism or neoliberalism. Islam does not set out a specific way to manage international relations, though in practice, it contributed to the emergence of a binary worldview differentiating between the Umma and others (Saeed 2006: 6; Bennison 2009: 45). The norm of waging wars belonged to the latter region (dar al-harb). This normative distinction was reinforced by the imperial heritage of Middle Eastern political communities which was also based on such a dichotomy-institutions outside of the borders of the empire are not recognised as legitimate (Steunebrink 2008: 10). A similar logic was inherited by the Arab states-as most of their constitution proclaims that they are part of the Arab nation, they officially constitute a region where war is not acceptable. This is a great feature of the MENA interstate society for small states as a traditional armed conflict is on top of their concerns.

Naturally, as I already mentioned, this normative particularity did not mean the elimination of all hostile competition. Arab togetherness did not eliminate conflict; it just reshaped the way in which conflict was managed. There are at least two ways 
in which we can see the limitation of the above described development: First, connected to the distinct nature of statehood described in the second part, intervening in each others' affairs has been common (Halliday 2009: 15-17).

Second, as Arab nationalism got weaker after the failed Arab-Israeli conflict, so did the norm of prohibiting inter-Arab wars. This process of normative fragmentation (Barnett 1998) (which coincided with the Iraqi-Kuwaiti war as well, causing additional division in the Arab world) resulted in decrease in pan-Arab togetherness and the rise of regional identities and in the weakening of the prohibition of interstate conflicts.

This shows that this prohibition has never been deeply institutionalised (Hinnebusch 2014: 17). The most important derivative secondary institution of the management of intra-Arab affairs has been the League of Arab States. This secondary institution will be the subject of the following case study.

\section{Case study: The League of Arab States as the protector of small states}

The League of Arab States (or the Arab League) was created in 1945 as the first regional organisation in the United Nations framework. According to its Charter (Mithaq Jamiah al-Daul al-Arabiyah wa-Mullaqatihu 2017), the primary norms it seeks to protect in the Arab world are cooperation, independence and sovereignty.

Naturally, many criticise the Arab League of being an ineffective, only nominally functioning organisation without any substance (Little 1956; Toffolo 2008: 121-122). Farah Dakhlallah argues that the League is a "product of the dilemma between state sovereignty and Arab nationalism" and thus has been unable to work effectively (Dakhlallah 2012: 393). Despite the truthfulness of such criticism, I would like to argue that the Arab League plays a highly relevant normative role in the Middle Eastern interstate society.

The importance of the Arab League for small states is twofold. First, it creates and reproduces the culture of consensus-based intergovernmental cooperation based on the respect of equality deriving from the mutual acceptance of sovereignty (Hinnebusch 2014; Murden 2009). This provides a great environment for small states as it deprives status-seeking great powers to force their will on others in the Arab League framework.

Small member states of the institution have always played an active role in both the creation and the operation of the League (Solingen 2008: 284-285). One way in which they contributed to the work was participating in mediation-between 1945 and 2000, they played a role in $45 \%$ of all facilitation talks in the Arab League framework (Yassine-Hamdan and Pearson 2014: 93-94).

The other way in which the Arab League plays an important role for small states is the normative protection gained by membership. As the League itself is a derivative institution of the Arab identity and togetherness, membership can be translated as a recognition of being part of the Arab interstate society. This, in practice, means a normative (not actual) protection from external attacks.

A prime example of the manifestation of such defence mechanisms was the membership bid of Kuwait (Yassine-Hamdan and Pearson 2014: 117-126). Before 
gaining independence in June 1961, the emirate was a British protectorate; therefore, the external defence of the territory was provided by London. Right before and after the Kuwait became a full-fledged independent state, the Iraqi prime minister repeatedly declared that Kuwait belongs to Iraq (Podeh 2003: 103.). The crisis got global as the Security Council met to discuss the possible alternatives, with a strong British and Soviet involvement. Nonetheless, the Sabah regime turned to the League of Arab States as well, and one of the first diplomatic steps it took was to apply for membership in the organisation. The most probable explanation for this move was the perception of the protective function of the membership. As it was predictable, Iraq immediately rejected the membership proposition, but other states (first and foremost Saudi Arabia) supported the Kuwaiti side.

The secretary-general of the League, Abdel Khalek Hassouna, decided to mediate between the stakeholders. According to Ahmed Al-Rashidi (Al-Rashidi 1992: 38-42), he wanted to make the involving actors to accept four basic principles for conflict management:

- exclusion of non-Arab actors (primarily the Security Council);

- finding a peaceful solution to avoid non-Arab military intervention;

- avoiding a rift in Arab nationalism by accepting Kuwait as an independent member of the Arab society;

- maintaining unity among Arab states.

These principles show clearly how Arab nationalism and togetherness are connected to sovereign equality and the normative protection deriving from it for all member states, let them be small or large. It also shows that this phenomenon is also connected to the perception of the penetrated nature of the MENA regionthe urge to avoid foreign intervention and the desire to find Arab solutions to Arab problems incentivise unity and cooperation over conflict.

Eventually, the conflict was resolved by an Arab League council meeting taking place on the 20th of July. On the peak of the debate, the Iraqi diplomats left the negotiations, after which all remaining members accepted the membership bid of Kuwait. The fact that Iraq acquiesced to the decision and did not attack the country (at least until 1990) shows that membership did provide protection to Kuwait.

It is important to mention that the crisis and the activities of Hassouna (himself being an Egyptian citizen) can also be interpreted as the actions of Nasser in the context of an Egyptian-Iraqi fight for power (Podeh 2003). This narrative does not contradict the previously outlined one about the protective role of membership as they are highly compatible with each other. The normative environment of the Middle Eastern society does not prohibit states to pursue their interests, but it creates an environment in which, according to Barnett (quoted by Podeh 2003), "state interests are legitimised with reference to a normative order, and the regional [Arab] order is still secured through negotiations and not military coercion alone".

Naturally, the process of normative fragmentation questions whether the Arab League can continue to provide such a role in the Middle Eastern society. Notwithstanding, surprisingly enough, we can see a very similar function for the 
organisation during the Arab Uprisings, though from a contradicting way. In 2011, first time in its history, the League decided to expel Libya from its members referring to humanitarian concerns, and at the same time, it endorsed a military intervention against the Qaddafi regime (Wajner and Kacowicz 2018: 504-505). Though the intervention itself was not organised by Arab states (as it was built up by Western countries on the basis of UNSCR 1973), two Arab countries, namely Qatar and the UAE, participated. This case, again, clearly shows the connection between membership and the prohibition of war. Contrarily, the Arab League provided legitimacy for the Bahraini regime in 2011 by not attempting to withdraw its membership.

A similar process took place with Syria, when the Arab League (after a quick mediation attempt) suspended its membership in November 2011 and introduced sanctions against the Assad regime. After that, several Arab states intervened in the civil war, mostly in support of the opposition (Küçükkeleş 2012). Eight years later, the reintegration of Syria to the Arab interstate society slowly started, but it probably only be concluded with the reinstallation of its membership in the League of Arab States.

\section{Conclusion: altering the vocabulary of small state studies}

The aim of the study was to investigate how mainstream theories of small state studies should be altered to be applicable to regions outside of Europe, more specifically to the MENA region. I argued that that the neorealist and neoliberal school have been designed to analyse mostly the small states of the Western segment of the international society, but they neglect possible alterations which are visible in other regions. That is why they fail to interpret the leverage of Middle Eastern small states in a comprehensive manner.

When it comes to the necessary modifications, I argued that two have to be made to analyse the foreign policy of small Middle Eastern states. First of all, the phenomenon of modern statehood is heavily altered in the MENA region, which manifests itself mostly in the regime structure and the penetrability of state borders, which forces states to omni-balance. This means that it will be social homogeneity and intra-regime dynamics which determine the leverage of governments and not necessarily the size of the state Secondly, norms related to conflict and cooperation provides some level of security to small Arab states as Arab solidarity (even today) prohibits the initiation of interstate wars between members of the Arab community.

The relevance of these two modifications is not limited to the MENA region as the norms related to statehood, sovereignty, conflict and cooperation are not equal in different regional systems in the world. Consequently, both the theories of small state studies and its vocabulary need to change to be applicable to regions outside of Europe. Focusing solely on states as actors is not sufficient enough due to various manifestations of statehood in the world. To understand how smallness effects political players, we should be open to institutions different from the Westphalian state.

Analysing the behaviour of "small regimes" presents such a possibility by taking into account the process of norm subsidiarity taking place in societies like that 
of the Middle East. This model can be used in other parts of the world too, though not automatically - specific changes of the norms of state, sovereignty, conflict and cooperation should be analysed as well to reflect the complexity of political communities. This is the only way to thoroughly understand the dynamics between small and large, as well as strong and weak actors in the international community.

Funding Open access funding provided by Corvinus University of Budapest.

\section{Compliance with ethical standards}

Conflict of interests On behalf of all authors, the corresponding author states that there is no conflict of interest.

Open Access This article is licensed under a Creative Commons Attribution 4.0 International License, which permits use, sharing, adaptation, distribution and reproduction in any medium or format, as long as you give appropriate credit to the original author(s) and the source, provide a link to the Creative Commons licence, and indicate if changes were made. The images or other third party material in this article are included in the article's Creative Commons licence, unless indicated otherwise in a credit line to the material. If material is not included in the article's Creative Commons licence and your intended use is not permitted by statutory regulation or exceeds the permitted use, you will need to obtain permission directly from the copyright holder. To view a copy of this licence, visit http://creativecommons.org/licen ses/by/4.0/.

\section{References}

Acharya, A. 2011. Norm Subsidiarity and Regional Orders: Sovereignty, Regionalism and Rule-Making in the Third World. International Studies Quarterly 55 (1): 95-123.

Archer, C., A.J.K. Bailes and A. Wivel (eds.). 2014. Small States and International Security. Europe and Beyond. New York \& London: Routledge.

Al-Rashidi, A.A. 1992. Watheefet Jami'at Al-Duwal Al-Arabeyeh Fi Mejal Al-Tesweyeh Al-Silmeyeh [The Role of the Leage of Arab States in Peaceful Settlement of Disputes]. Cairo: Arab Center on Development and Future Research.

Anderson, L. 1987. The State in the Middle East and North Africa. Comparative Politics 20 (1): 1-18.

Baldacchino, G. 2014. The Security Concerns of Designed Spaces: Size Matters. In Small States and International Security. Europe and Beyond, ed. C. Archer, A.J.K. Bailes, and A. Wivel, 241-254. New York \& London: Routledge.

Barany, Z. 2012. The 'Arab Spring' in the Kingdoms. Arab Center for Research \& Policy Studies, September, https://www.dohainstitute.org/en/lists/ACRPS-PDFDocumentLibrary/The_Arab_Sprin g_in_the_Kingdoms.pdf. Accessed 4 January 2020.

Barnett, M. 1998. Dialogues in Arab Politics: Negotiations in Regional Order. New York: Columbia University Press.

Bennison, A.K. 2009. The Ottoman Empire and its Precedents from the Perspective of English School Theory. In International Society and the Middle East. English School Theory at the Regional Level, ed. B. Buzan and A. Gonzalez-Pelaez, 45-70. New York: Palgrave MacMillan.

Brichs, F.I. 2013. Introduction. In Political Regimes in the Arab World, ed. F.I. Brichs, 1-5. New York: Routledge.

Brichs, F.I., and A. Lampridi-Kemou. 2013. Sociology of Power in Today's Arab World. In Political Regimes in the Arab World, ed. F.I. Brichs, 6-35. New York: Routledge.

Bull, H. 2002. The Anarchical Society: A Study of Order in World Politics, 3rd ed. London: Macmillan.

Buzan, B. 2004. From International to World Society? English School Theory and the Social Structure of Globalisation. Cambridge: Cambridge University Press. 
Buzan, B., and R. Little. 2014. The Historical Expansion of International Society. In Guide to the English School in International Studies, ed. C. Navari and D. Green, 59-76. West Sussex: Wiley Backwell.

Buzan, B., and A. Gonzalez-Pelaez (eds.). 2009. International Society and the Middle East. English School Theory at the Regional Level. New York: Palgrave MacMillan.

Byman, D.L., and J.D. Green. 1999. The Enigma of Political Stability in the Persian Gulf Monarchies. Middle East Review of International Affairs 3 (3): 1-20.

Chong, A., and M. Maas. 2010. Introduction: The Foreign Policy Power of Small States. Cambridge Review of International Affairs 23 (3): 381-382.

Chong, A. 2014. Small State Security in Asia: Political and Temporal Constructions of Vulnerability. In Small States and International Security. Europe and Beyond, ed. C. Archer, A.J.K. Bailes, and A. Wivel, 202-222. New York \& London: Routledge.

Colombo, S. 2017. Foreign Policy Activism in Saudi Arabia and Oman. Diverging Narratives and Stances towards the Syrian and Yemeni Conflicts. The International Spectator 52 (2): 54-70.

Commins, D. 2014. The Gulf States. A Modern History. London: I. B. Tauris.

Coporaso, J.A. 2000. Changes in the Westphalian order: Territory, public authority, and sovereignty. International Studies Review 2 (2): 1-28.

Costa-Brunelli, F. 2015. 'Do you know what I mean?' 'Not exactly': English School, global international society and the polysemy of institutions. Global Discourse 5 (3): 499-514.

Crystal, J. 2014. Eastern Arabian States: Kuwait, Bahrain, Qatar, United Arab Emirates, and Oman. In The government and politics of the Middle East and North Africa, 7th ed, ed. M. Gasirowski, 157196. Boulder: Westview Press.

Dakhlallah, F. 2012. The League of Arab States and Regional Security: Towards an Arab Security Community? British Journal of Middle Eastern Studies 39 (3): 393-412.

David, S.R. 1991. Third World Alignment. World Politics 43 (2): 233-256.

Davidson, C.M. 2012. After the Sheikhs. The Coming Collapse of the Gulf Monarchies. London: Hurst \& Co.

Diwan, K.S. 2014. Royal Factions, Ruling Strategies, and Sectarianism in Bahrain. In Sectarian Politics in the Persian Gulf, ed. L.G. Potter, 143-178. Oxford: Oxford University Press.

Fuccaro, N. 2009. Histories of City and State in the Persian Gulf. Manama since 1800. Cambridge: Cambridge University Press.

Freer, C. and G. Cafiero. 2017. Is the Muslim Brotherhood's 'Special Status' Over? The New Arab, August 7, https://www.alaraby.co.uk/english/comment/2017/8/7/is-the-bahraini-muslim-brotherhoo ds-special-status-over. Accessed 4 January 2020.

Gengler, J. 2013. Royal Factionalism, the Khawalid, and the Securitization of 'the Shi'a Problem' in Bahrain. Journal of Arabian Studies 3 (1): 53-79.

Gigleux, V. 2016. Explaining the Diversity of Small States' Foreign Policies through Role Theory. Third World Thematics 1 (1): 27-45.

Guzansky, Y. 2015. The Arab Gulf States and Reform in the Middle East. New York: Palgrave Macmillan.

Halliday, F. 2009. The Middle East and Conceptions of 'International Society'. In International Society and the Middle. East English School Theory at the Regional Level, ed. B. Buzan and A. Gonzalez-Pelaez, 1-23. New York: Palgrave MacMillan.

Hinnebusch, R. 2014. The Middle East Regional System. In The Foreign Policies of Middle East States, 2nd ed, ed. R. Hinnebusch and A. Ehteshami, 35-74. London: Lynne Rienner Publishers.

Hinnebusch, R. 2018. From Westphalian Failure to Heterarchic Governance in MENA: The Case of Syria. Small Wars \& Insurgencies 29 (3): 391-413.

Jackson, R. 2009. Regime Security. In Contemporary Security Studies, ed. A. Collins, 146-164. Oxford: Oxford University Press.

Ismael, T.Y., and J.S. Ismael. 2011. Government and Politics of the Contemporary Middle East. Continuity and Change. London \& New York: Routledge.

Jackson, R.H., and C.G. Rosberg. 1982. Why Africa's Weak States Persist: The Empirical and Juridical in Statehood. World Politics 35 (1): 1-24.

Kamrava, M. 2013. Qatar: Small State, Big Politics. London: Cornell University Press.

Kamrava, M. 2014. The Foreign Policy of Qatar. In The Foreign Policies of Middle East States, 2nd ed, ed. R. Hinnebusch and A. Ehteshami, 157-184. London: Lynne Rienner Publishers.

Katzenstein, P.J. 1985. Small States in World Markets. Industrial Policy in Europe. Itacha \& London: Cornell University Press.

Kausch, K. 2014. Competitive Multipolarity in the Middle East, Istituto Affari Internazionali. 10 September, https://www.iai.it/en/pubblicazioni/competitive-multipolarity-middle-east-0. Accessed 4 January 2020. 
Kausch, K. 2017. Proxy Agents: State and Non-State Alliances in the Middle East. In: Lorenzo Kamel (ed.) The Frality of Authority. Borders, Non-state Actors and Power Vacuums in a Changing Middle East. Istituto Affari Internazionali, 67-84. http://www.iai.it/sites/default/files/newmed_authority.pdf. Accessed 4 January.

Khalaf, A. 2013. Squaring the Circle: Bahrain's Pearl Roundabout. Middle East Critique 22 (3): 265-280.

Kinninmont, J. 2011. Bahrain. In Power and Politics in the Persian Gulf Monarchies, ed. C. Davidson, 31-62. London: Hurst \& Company.

Küçükkeleş, M. 2012. Arab League's Syrian Policy. SETA Foundation for Political, Economic and Social Research, April, http://file.setav.org/Files/Pdf/arab-league\%E2\%80\%99s-syrian-policy.pdf. Accessed 4 January 2020.

Lawson, F.H. 2000. Westphalian Sovereignty and the Emergence of the Arab States System: The Case of Syria. The International History Review 22 (3): 529-556.

Little, T.R. 1956. The Arab League: A Reassessment. Middle East Journal 10 (2): 138-150.

Louer, L. 2014. The State and Sectarian Identities in the Persian Gulf Monarchies. Bahrain, Saudi Arabia, and Kuwait in Comparative Perspectives. In Sectarian Politics in the Persian Gulf, ed. L.G. Potter, 117142. Oxford: Oxford University Press.

Maas, M. 2005. Small States and the International Society of States. International Studies Association Annual Conference. March, http://citation.allacademic.com//meta/p_mla_apa_research_citat ion/0/6/9/3/6/pages69364/p69364-1.php. Accessed 4 January 2020.

Marchetti, R. and Y. Al Zahrani. 2017. Hybrid Partnerships in Middle East Turbulence. In: L. Kamel (ed.) The Frality of Authority. Borders, Non-state Actors and Power Vacuums in a Changing Middle East. Istituto Affari Internazionali, 07-122. http://www.iai.it/sites/default/files/newmed_authority.pdf. Accessed 4 January 2020.

Matthiesen, T. 2013. Sectarian Gulf. Bahrain, Saudi Arabia and the Arab Spring that Wasn't. Stanford: Stanford University Press.

Middle East Eye. 2018. UAE and Saudi Arabia behind Push to Topple Bahrain's PM: Source. Middle East Eye, 7 January, http://www.middleeasteye.net/news/uae-and-saudi-arabia-pushing-upheaval-bahraingovernment-source-826891255. Accessed 4 January 2020.

"Mithaq Jamiah al-Daul al-Arabiyah wa-Mullaqatihu". 2017. [The Charter of the League of Arab States and its Annexes]. http://www.lasportal.org/ar/aboutlas/Pages/Charter.aspx.

Murden, S.W. 2009. The Secondary Institutions of the Middle Eastern Regional Interstate Society. In International Society and the Middle East. English School Theory at the Regional Level, ed. B. Buzan and A. Gonzalez-Pelaez, 117-139. New York: Palgrave MacMillan.

Narine, S. 2006. The English School and ASEAN. The Pacific Review 19 (2): 199-218.

Neal, A.W. 2017. Security in a Small Nation. Scotland, Democracy, Politics. Cambridge: Open Book Publishers.

Neumann, I.B., and S. Gstöhl. 2006. Introduction. Lilliputians in Gulliver's World? In Small States in International Relations, ed. C. Igebritsen, I.B. Neumann, S. Gstöhl, and J. Beyer, 3-39. Reykjavik: University of Iceland Press.

Northedge, F.S. 1976. The International Political System. London: Faber \& Faber.

N. Rózsa, E. 2018. Models of State-Formation in the Middle East. Asian Journal of Middle Eastern and Islamic Studies 12 (1): 16-34.

Podeh, E. 2003. Suez in reverse: The Arab response to the Iraqi bid for Kuwait, 1961-63. Diplomacy \& Statecraft 14 (1): 103-130.

Saeed, A. 2006. Islamic Thought. An Introduction. New York: Routledge.

Salzman, P.C. 2016. Tribes and Modern States: An Alternative Approach. In Tribes and States in the Changing Middle East, ed. U. Rabi, 207-2019. London: Hurst \& Co.

Schouenborg, L. 2014. The English School and Institutions: British Institutionalists? In Guide to the English School in International Studies, ed. C. Navari and D. Green, 77-90. Oxford: Wiley Blackwell.

Sharabi, H. 1988. Neopatryarchy. A Theory of Distorted Change in Arab Society. Oxford: Oxford University Press.

Solingen, E. 2008. The Genesis, Design and Effects of Regional Institutions: Lessons from East Asia and the Middle East. International Studies Quarterly 52 (2): 261-294.

Stivachtis, Y.A. 2008. Civilization and International Society: The Case of European Union Expansion. Contemporary Politics 14 (1): 71-89.

Steunebrink, G. 2008. Sovereignty, the Nation State and Islam. Ethical Perspectives 15 (1): 7-47.

Taylor, I. 2014. Botswana as a Small Development State. In Small States and International Security. Europe and Beyond, ed. C. Archer, A.J.K. Bailes, and A. Wivel, 187-201. New York \& London: Routledge. 
Thorhallson, B. 2006. The Role of Small States in the European Union. In Small States in International Relations, ed. C. Igebritsen, I.B. Neumann, S. Gstöhl, and J. Beyer, 218-231. Reykjavik: University of Iceland Press.

Toffolo, C.E. 2008. Global Organizations: The Arab League. New York: Infobase Publishing.

Ulrichsen, C.K. 2014. Bahrain's Uprising: Domestic Implications and Regional and International Perspectives. In The New Middle East. Protest and Revolution in the Arab World, ed. F. Gerges, 332-352. Cambridge: Cambridge University Press.

Valensi, C. 2015. Non-state Actors: A Theoretical Limitation in a Changing Middle East. Military and Strategic Affairs 7 (1): 59-78.

Veenendaal, Wouter. 2020. Does Smallness Enhance Power-Sharing? Explaining Suriname's Multiethnic Democracy. Ethnopolitics 19 (1): 64-84.

Vital, D. 1967. The Inequality of States: A Study of the Small Power in International Relations. Oxford: Oxford University Press.

Wajner, D.F., and A.M. Kacowicz. 2018. The quest for regional legitimation: Analyzing the Arab League's legitimizing role in the Arab spring. Regional \& Federal Studies 28 (4): 489-521.

Waltz, K.N. 1979. Theory of International Politics. Reading: Addison-Wesley.

Waltz, K.N. 1999. Globalisation and Governance. Political Science and Politics 32 (4): 693-700.

Wehrey, F.C. 2013. Sectarian Politics in the Gulf. From the Iraq War to the Arab Uprisings. New York: Columbia University Press.

Wight, M. 1978. Power Politics. London: Chatham House.

Wivel, A., A.J.K. Bailes, and C. Archer. 2014. Setting the Scene: Small States and International Security. In Small States and International Security. Europe and Beyond, ed. C. Archer, A.J.K. Bailes, and A. Wivel, 3-25. New York \& London: Routledge.

Yassine-Hamdan, N., and F.S. Pearson. 2014. Arab Approaches to Conflict Resolution. Mediation, Negotiation and Settlement of Political Disputes. London \& New York: Routledge.

Yost, D.S. 1979. New Perspectives on Historical State-Systems. World Politics 32 (1): 151-168.

Publisher's Note Springer Nature remains neutral with regard to jurisdictional claims in published maps and institutional affiliations. 